\title{
Schistosomahaematobium and Urogenital Disorders
}

\author{
Maria Amélia A Grácio* \\ Instituto de Higiene e Medicina Tropical, Universidade Nova de Lisboa, Portugal
}

Received: 眥 February 23, 2018; Published: 㦸 February 26, 2018

*Corresponding author: Maria Amélia A Grácio, Instituto de Higiene e Medicina Tropical, Universidade Nova de Lisboa, Rua da Junqueira 100, 1349- 008 Lisboa, Portugal

\section{Introduction}

Schistosomiasis, also known as bilharziasis, is one of the most serious of tropical diseases that occurs in the world. In fact, schistosomiasis has been reported from 76 countries, being:

I. Intestinal schistosomias is caused by

a. Schistosoma mansoni recorded in Africa, the Middle East, the Caribbean, Brazil, Venezuela, and Suriname

b. S. japonicum in China, Indonesia and the Philippines

c. S. mekongi in several districts of Cambodia and the Lao people's Democratic Republic

d. S. guineensis and related S. intercalatum recorded in rain forest of Central Africa

II. Urogenital schistosomiasis caused by $S$. haematobium recorded in Africa, the Middle East, Corsica (France) [1].

Concerning Europe, we are in the presence of a re-introduction of this disease, since it had been recorded in Portugal, where several foci had occurred in Algarve-Southern Portugal [2,3] Still in Europe, the record of new localization of intermediate hosts of $S$. haematobium can be a risk of expansion of this parasite in European continent $[4,5]$. S. haematobium is a blood fluke and part of its development occurs within freshwater snails (intermediate hosts) and the diseases is contracted when cercariae larvae (infectant stage for humans) are liberated from the snails and penetrate the skin of anyone that is in contact with infected water (bath, domestic activities, fishing, etc.,). The cercariae, after penetration are known as schistosomulae. These migrate and develop into mature adult schistosoma worms, their habitat being inside blood vessels. Then, the adults inhabit the veins of the vesical plexus, although some parasites may live in the portal vein and its mesenteric branches. Oviposition normally occurs in the small terminal venules of the vesical plexus, but occasionally in the rectal venules, the mesenteric portal system and ectopic sites. Ectopic migration of the $S$. haematobium adults and Oviposition can occur anywhere in the body, resulting in a variety of lesions [6].
Concerning reproductive organs, the female genital tract is frequently found to harbor S. haematobium ova [7], and ova have been found at autopsy in the vas deferents, prostate, scrotal skin pampiniforme plexus and epididymis [8,9]. Urogenital schistosomiasis presenting genital and urinary tract lesions has been referred by several authors, as well as responsible for female sterility and it can affect up to $50 \%$ of women with S. haematobium infection in endemic areas. Even in the absence of urinary ova excretion, $23-41 \%$ of women have been found to suffer from genital of schistosomiasis [10]. Urogenital schistosomiasis associated with cases of female sterility have been observed [11,12]. The histophatology of 176 cases of schistosomiasis reported from Malawi during the period 1976-1980 has showed schistosomiasis infection throughout the genital tract with $60 \%$ of cases including the cervix. Schistosomiasis was a significant case of gynecological morbidity, particularly when infection involved the lower genital tract, however in a proportion of cases ova were found coincidentally in other lesions or normal tissues, and were not apparently causally linked with symptoms [13].

Another aspect deserving attention is the association between urogenital schistosomiasis and cancer observed in men. Effectively, cases of prostate carcinoma associated with schistosomiasis have been published worldwide [14]. For that if can to have a general idea of the potential risk of urogenital disorders in the world, we also make here a short information on urogenital schistosomiasis in European travelers and migrants. Then, according to TropNet Surveillance Data [15], in an analysis of 14 years- from 1997 to 2010- on urogenital schistosomiasis due S. haematobium in European travelers and migrants, the species information was available in 898/1,465 (61\%) of the cases (young with an median age of 29). Urogenital schistosomiasis due to $S$. haematobium was diagnosed in $22 \%$ of cases $(318 / 1,465)$. Among these $63.8 \%$ $(203 / 318)$ were found in non-European, $4.7 \%$ (15/318) among expatriates, and 31.5\% (100/318) among Europeans. The authors have concluded, "That schistosomiasis remains a relevant infection in travelers and migrants in Europe. Most infections in Europeans 
occur in travelers visiting a small number of countries in west and east Africa. These travelers should be counseled intensively on the risk of schistosomiasis infection."

To avoid the serious consequences of urogenital schistosomiasis prevention and early treatment should be an important health care target in endemic areas [16]. Also schistosomiasis needs to be considered as a differential diagnosis of female infertility and sterility [11]. Finally, we are in agreement with [17] in the following "considering that female genital schistosomiasis is a significant risk for ectopic pregnancy and infertility in schistosomiasis endemic areas a detailed histology is necessary and parasitic evaluation of patients presenting with ectopic pregnancy or sub fertility in areas where the disease is endemic, and with [18] "the scarcity of integrated approaches to address female genital schistosomiasis from case reports to a call for concerted actions against this neglected gynecological disease".

\section{References}

1. (2017) WHO. Fact sheet updated October 2017.

2. Azevedo JF de, Silva JB de, Coito AM, Coelho MF, Colaço A (1948) O foco português de schistosomiase. Anais InstMedtrop 5: 275-222.

3. Grácio MA (1983) Distribution and habitats do six species of freshwater pulmonate snails in Algarve, southern Portugal. Malacological Review 161(2): 27-23.

4. Grácio MA, Richter J (2015) Risk of expansion of S. haematobiumin Europe. XIX SOCEPA- II Encuentro International de Parasitólogos de España, Francia, Italia, Portugal - Vitória, Gasteiz, p. 23-25.

5. Dana EO, Garcia-de-Lomss J, Juan Baños JL, Esteban E, Grácio MAA, et al (2015) New location for Bulinustruncatus (Audouin, 1827, Gastropoda: Planorbidae) intermediate host of Schistosoma haematobium and its distribution in the Iberian Peninsula. Graelllsia 71(2): 030.

6. Eddington GM, Nwabuelo I, Junaid TA (1975) The pathology of schistosomiasis in Ibadan Nigeria with special reference to the appendix, brain, pancreas and genital organs. Trans R Soc trop Med Hyg 69(1): 153-156.

7. Gelfand M, Ross CMD, Blair DM, Weber MC (1971) Distribution and extent of schistosomiasis in female pelvic organs with special references to the genital tract as determined at autopsy. Am trop Med Hyg 20(6): 846-849.
8. Gelfand M, Ross CMD, Blair DM, Castle WM, Weber MC (1970) Schistosomiasis of the male pelvic organs. Severity of infection as determined by digestion of tissues and histologic methods in 300 cadavers. Am J trop Med Hyg 19(5): 779-784.

9. Kazzaz BA, Salmo NA (1974) Epididymitis due to Schistosomahaematobium infection. Trop Geog Med 26(3): 333-336.

10. Kjetland EF, Ndhlown PD, Kurewa EN, Midzi N, Gomo E, et al. (2008) Prevention of genicologic contact bleeding and genital sandy practics by child- blood anti-schidtosomal treatment. Am J trop Med Hyg 79: 79-83.

11. Schanz A, Richter J, Breyer I, Baldus F, Hess AQP, et al. (2010) Genital schistosomiasis as a case of female sterility and acute abdomen. Fertility and Sterility 93(6): 2075-2077.

12. Figueiredo J, Richter J, Belo S, Grácio MA (2013) Urogenital schistosomiasis presenting genital and urinary tract lesions and abdominal discomfort in a steril Angolan woman. J Genit Syst Disor 2(3): $1-4$.

13. Wright SD, Chiphangwi J, Hutt MSR (1982) Schistosomiasis of the female genital tract. A histophathologic study of the 176 cases from Malawi. Trans Roy Soc trop Med Hyg 76(6): 822-829.

14. Figueiredo JC, Richter J, Nilo B, Balaca A, Grácio MA, et al. (2014) Prostate adenocarcinoma associated with prostatic infection due to Schistosomahaematobium. Case report and systematic review. Parasitol Res 114(2): 351-358.

15. Lingescheid T, Kurth F, Clerinx J, Marocco S, Schunk M, et al. (2017) Schistosomiasis in European Travelers and Migrants: Analysis of 14 Years TropNet Surveillance Data. Am J trop Med Hyg 97(2): 567-574.

16. Khalaf J, Shoker A (2010) Genitourinary schistosomiasis. Urogenital infections. European Association of Urology, Netherlands pp. 943-958.

17. Owusu BA, Odoi AT, Dassah ET (2013) Genital schistosomiasis leading to ectopic pregnancy and subfertility. A case for parasitic evaluation of gynaecologic patients in schistosomiasis endemic areas. Case Reports in Obstetrics and Gynecology p. 1-10.

18. Christinet V, Lazdins-Helds JK, Stothard JR, Reinhard-Rupp (2016) Female genital schistosomiasis (FGS) from case reports to a call for concerted action against this neglected gynaecological disease. Int J Parasitol 46(7): 395-404.

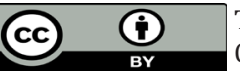

This work is licensed under Creative Commons Attribution 4.0 License

Submission Link:

Submit Article

DOI: 10.32474/OAJRSD.2018.01.000106

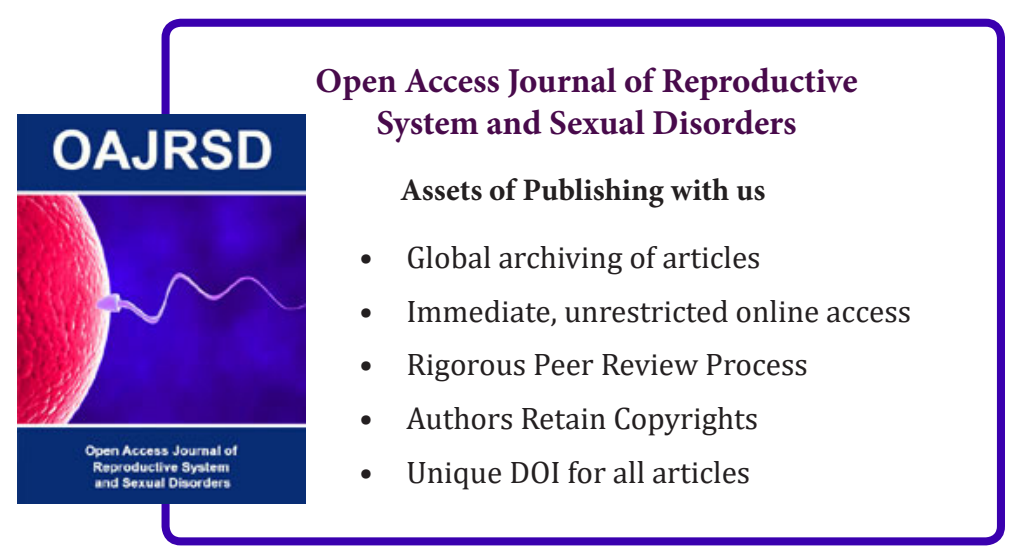

